\title{
Peran Moral Reasoning dan Skeptisisme Profesional Memoderasi Role Stress Terhadap Perilaku Disfungsional Internal Auditor
}

\author{
Christina Ayu Maha Dewi ${ }^{1}$ \\ Anak Agung Ngurah Bagus Dwirandra
}

${ }^{1}$ Fakultas Ekonomi dan Bisnis Universitas Udayana (Unud), Bali, Indonesia email: christina.dewi88@yahoo.com/telp: +6281338558582

${ }^{2}$ Fakultas Ekonomi dan Bisnis Universitas Udayana (Unud), Bali, Indonesia

\begin{abstract}
ABSTRAK
Perilaku disfungsional auditor harus dihindari untuk menghasilkan temuan audit yang berkualitas berdasarkan kewajaran sebuah laporan keuangan. Tujuan dari penelitian ini adalah menganalisis peran moral reasoning dan skeptisisme profesional memoderasi role stress terhadap perilaku disfungsional auditor di PT Bank BRI Wilayah Bali-Nusra. Penelitian ini dilakukan di seluruh kantor Kantor Cabang PT Bank BRI Wilayah Bali-Nusra sebanyak 29 kantor dengan menjadikan auditor sebanyak 107 orang sebagai sampel dengan metode sample jenuh di uji melalui teknik moderasi regresi analisis (MRA). Berdasarkan hasil analisis, variabel role stress memiliki peran dalam meningkatkan perilaku disfungsional auditor pada PT Bank BRI Wilayah Bali-Nusra. Moral reasoning memiliki peran dalam meningkatkan perilaku disfungsional auditor pada PT Bank BRI Wilayah Bali-Nusra. Skeptisisme profesional memiliki peran dalam meningkatkan perilaku disfungsional auditor. Moral reasoning mampu memperkuat pengaruh role stress dalam meningkatkan perilaku disfungsional auditor. Skeptisisme profesional mampu memperkuat pengaruh role stress dalam meningkatkan perilaku disfungsional auditor.
\end{abstract}

Kata kunci: role stress, moral reasoning, skeptisisme profesional, perilaku disfungsional auditor

\begin{abstract}
Dysfunctional behavior of the auditor should be avoided to produce quality audit findings based on the fairness of a financial statement. The purpose of this study is to analyze the role of moral reasoning and professional skepticism moderating role stress on dysfunctional behavior of auditors. This research was conducted in all branch offices of PT Bank BRI Bali-Nusra Area as many as 29 offices by making the auditor as many as 107 people as sample with saturated sample method in test through regression analysis moderation technique (MRA). Based on the results of the analysis, role stress variables have a role in increasing dysfunctional behavior of auditors. Moral reasoning has a role in increasing dysfunctional behavior of auditors. Professional skepticism has a role in increasing dysfunctional behavior of auditors. Moral reasoning and Professional skepticism can strengthen the influence of role stress in increasing dysfunctional behavior of auditors.

Keywords: role stress, moral reasoning, professional skepticism, auditor dysfunctional behavior
\end{abstract}


Christina Ayu Maha Dewi dan Anak Agung Ngurah Bagus Dwirandra. Peran...

\section{PENDAHULUAN}

Negara Indonesia merupakan negara berkembang dimana pembangunan perekonomian sangat mempengaruhi perkembangan negara tersebut. Salah satu penunjang yang dapat menggerakan roda perekonomian suatu negara adalah perbankan (Kasmir, 2008:56). Perbankan saat ini mempunyai peranan yang sangat penting dalam pelaksanaan pembangunan nasional untuk meningkatkan pertumbuhan ekonomi dan stabilitas masyarakat dalam rangka meningkatkan taraf hidup rakyat (Dikdik, 2008).

Pendapatan pada dasarnya dapat diperoleh terutama dari penjualan produk perbankan. Salah satu usaha bank untuk memperoleh pendapatan yaitu dengan menyediakan jasa perkreditan yang berupa bunga kredit, provisi serta komisi (Anggriawan, 2014). Pendapatan bank merupakan pendapatan dalam bentuk bunga yang diterima oleh pihak bank sebagai balas jasa dan biaya administrasi. Pendapatan bank ini diperlukan untuk kelangsungan hidup, disamping itu pendapatan ini juga dapat digunakan untuk membesarkan usaha bank (Faisal, 2007).

Fenomena masalah yang sering terjadi di perbankan dalam penyaluran kredit yang dilakukan dapat terjadi timbulnya kredit macet atau kredit bermasalah. Kredit macet atau kredit bermasalah merupakan suatu penyakit yang dapat menganggu dan mengancam sistem kegiatan bank, sehingga bank menjadi tidak sehat. Namun diakui bahwa sektor perkreditan tetap merupakan kegiatan yang penting dari suatu industri perbankan, karena "kredit" sebagai salah satu sumber dana yang penting untuk usaha perbankan. 
Salah satu bank yang ada di Indonesia yakni PT Bank BRI Kanwil BaliNusra. PT Bank BRI Kanwil Bali-Nusra untuk mengatasi terjadinya kecurangan (fraud) dibentuk audit internal sebagai biro pengawasan untuk mencegah kecurangan dalam suatu perusahaan yang kegiatannya meliputi menguji dan menilai efektivitas serta kecukupan sistem pengendalian internal yang ada dalam perusahaan. Untuk menghilangkan kebocoran dan kerugian negara dilakukan tindakan-tindakan pengawasan, hal ini adalah cara untuk mengatasi kecurangan sehingga kehilangan keuangan negara dapat terus ditekan dan pada akhirnya tercapai tujuan (Gaffikin \& Lindawati, 2012).

Suatu instansi perusahaan telah melaksanakan kegiatan sesuai dengan tugas dan fungsinya secara efektif dan efisien, serta sesuai dengan rencana, kebijakan yang telah ditetapkan melalui pengawasan intern dapat diketahui. Untuk mendorong terwujudnya good governance dan clean government, pengawasan intern juga diperlukan (Balkish et al., 2013).

Pengendalian atas aktivitas operasi bank meliputi pengendalian eksternal bank dan pengendalian internal bank. Pengendalian eksternal bank adalah berupa pemeriksaan kinerja bank umum oleh Bank Indonesia sebagai bank sentral serta pemeriksaan laporan keuangan bank umum oleh akuntan publik (Alvin et al., 2008:1). Adapun pengendalian internal bank umum berupa pengendalian atau kontrol yang akan diterapkan dalam sistem prosedur kegiatan operasional bank dan pemeriksaan intern secara berkala oleh auditor internal atas pelaksanaan aktivitas usaha bank berdasarkan pada Standar Pelaksanaan Fungsi Intern Bank (SPFAIB) tahun 1999 (Alvin et al., 2008:2). 
Christina Ayu Maha Dewi dan Anak Agung Ngurah Bagus Dwirandra. Peran...

Tujuan pemeriksaan internal adalah menilai efisiensi dan efektifitas pengendalian internal, Dengan adanya pemeriksaan internal yang memadai, maka manajemen dalam mengelola perusahaan selalu dituntut untuk memperoleh data yang benar dan dapat dipercaya mengenai segala kegiatan dalam perusahaan (Alvin et al., 2008:12). Terdapat hubungan yang erat antara pemeriksaan intenal dengan pengendalian internal karena bila pemeriksaan internal dilaksanakan dengan efektif, maka akan meningkatkan efektifitas pengendalian internal (Hanifah, 2017).

Seorang auditor internal dalam melaksanakan tugasnya melalui pola fungsi dan tugasnya diharapkan menghindari terjadinya perilaku disfungsional auditor (Rustiarini, 2014). Perilaku audit disfungsional adalah setiap tindakan yang dilakukan auditor dalam pelaksanaan program audit yang dapat mereduksi atau menurunkan kualitas audit secara langsung maupun tidak langsung (Kelley dan Margheim, 1990; Otley dan Pierce 1996) dalam Nelson (2009). Alkautsar (2014) perilaku disfungsional auditor dipengaruhi oleh role stress yang dialami oleh auditor.

Peran internal auditor di lingkungan perbankan sebagai pelaksana dari biro pengawasan dalam melakukan tugasnya tentunya juga tidak terlepas dari terjadinya konflik-konflik kepentingan, baik itu antar individu, antar departemen maupun antar individu dan perusahaan. Berbagai tekanan maupun konflik yang dialami oleh seorang internal auditor pada akhirnya akan bermuara pada terjadinya role stress (David et al., 2016) 
Berdasarkan penelitian yang dilakukan oleh Dikdik (2008) role stress didefinisikan sebagai suatu kondisi di mana seorang individu mengalami role conflict dan role ambiguity. Role stress yang terjadi pada akhirnya juga akan berpengaruh pada perilaku disfungsional auditor secara keseluruhan (Rebele dan Michaels, 1990).

Perilaku disfungsional auditor sebagai perilaku yang menyimpang dari seorang auditor tentu saja dipengaruhi oleh beberapa faktor diluar role stress, antara lain adalah moral reasoning. Menurut Syarhayuti \& Faidul (2016) moral reasoning didefinisikan sebagai alasan yang mendasari seseorang dalam melakukan suatu tindakan atau alasan yang mendasari seseorang dalam membenarkan ataupun mengkritik suatu perbuatan. Seorang auditor yang memiliki moral reasoning yang tinggi, akan lebih tepat dalam melakukan audit judgement, sehingga perilaku disfungsional auditor dapat dicegah atau dihindari. Penelitian Ceacilis et al. (2016) menemukan bahwa moral reasoning memiliki pengaruh terhadap pencegahan perilaku disfungsional auditor. Namun berbeda dengan hasil penelitian yang dilakukan oleh Alan \& Todd (2011) serta Gaffikin \& Lindawati (2012) yang menyimpulkan bahwa variabel moral reasoning berpengaruh positif terhadap perilaku disfungsional auditor.

Pentingnya moral reasoning sebagai variabel moderasi diartikan untuk mencari pemecahan atas sebuah masalah dengan menggunakan logika sehat. Sehingga moral reasoning bisa diartikan sebagai upaya kita memecahkan masalah moral dengan menggunakan logika sehat dengan pertimbangan-pertimbangan dengan cermat sehingga menghindari terjadinya perilaku disfungsional auditor. 
Christina Ayu Maha Dewi dan Anak Agung Ngurah Bagus Dwirandra. Peran...

Beberapa penelitian seperti Tangsakul \& Ussahawanitchakit (2015) menyatakan bahwa moral reasoning berpengaruh terhadap perilaku disfungsional auditor. Suriana (2014) menyatakan hal yang sama dimana moral reasoning memoderasi pengaruh role stress secara positif pada perilaku disfungsional auditor.

Begitu pentingnya hasil temuan audit yang diberikan oleh auditor bagi sebuah perusahaan, maka seorang auditor dituntut untuk menghindari terjadinya perilaku disfungsional, oleh karena itu seorang auditor harus melaksanakan sikap skeptisisme profesionalnya sehingga auditor dapat menggunakan kemahiran profesionalnya dengan cermat dan seksama, karena kemahiran profesional seorang auditor mempengaruhi ketepatan opini yang diberikannya untuk menghasilkan temuan audit yang berkualitas (Quadackers et al., 2008). Salah satu standar umum audit dinyatakan bahwa dalam pelaksanaan audit dan penyusunan laporan auditor wajib menggunakan kemahiran profesional dengan cermat dan seksama (Medhat \& Gary, 2015).

Auditor seringkali berada di situasi dilematis, dalam persaingan yang semakin ketat, tentu sikap skeptisisme profesional harus diterapkan dan merupakan hal penting dalam melakukan audit. Sebab pada kenyataannya sering kali waktu yang diberikan tidak realistis dibandingkan dengan pekerjaan yang harus dilakukannya, dan dapat berakibat terjadinya perilaku disfungsional auditor (Peyman \& Ali, 2016).

Pentingnya skeptisisme profesional sebagai variabel moderasi dapat diartikan untuk mengurangi risiko seperti misalnya kegagalan dalam melihat kondisi-kondisi tidak lazim, terlalu menyamarkan kesimpulan ketika menarik 
kesimpulan tersebut dari observasi audit dan menggunakan asumsi yang tidak tepat dalam menetapkan sifat, saat, dan luas prosedur audit serta penilaian atas hasilnya. Skeptisisme profesional sebagai variabel moderasi diperlukan dalam penilaian penting atas bukti audit sehingga menurunkan terjadinya perilaku disfungsional auditor. Beberapa penelitian seperti Medhat \& Gary (2015) menyatakan bahwa skeptisisme profesional berpengaruh terhadap perilaku disfungsional auditor. (Quadackers et al., 2008) menyatakan bahwa skeptisisme profesional secara tidak langsung mempengaruhi perilaku disfungsional auditor.

Auditor merupakan suatu profesi yang sangat penting untuk dikaji, dalam hal ini perilaku disfungsional auditor perlu dihindari sebagai tanggung jawab dalam melaksanakan pengawasan audit, sehingga dalam hal ini moral reasoning, skeptisisme professional perlu dilaksanakan untuk menghindari terjadinya role stress dan perilaku disfungsional auditor untuk meningkatkan hasil laporan audit.

Berdasarkan uraian latar belakang diatas dan ditunjang oleh hasil penelitian-penelitian terdahulu, maka penelitian ini dilakukan untuk mengetahui bagaimana pengaruh role stress, moral reasoning, dan skeptisme profesional pada perilaku disfungsional auditor dan bagaimanakah pengaruh moral reasoning dan skeptisme professional pada hubungan role stress dengan perilaku disfungsional auditor.

Tujuan penelitian ini untuk memeroleh bukti secara empiris mengenai pengaruh role stress, moral reasoning, dan skeptisme profesional pada perilaku disfungsional auditor dan untuk mengetahui pengaruh moral reasoning dan skeptisme professional pada hubungan role stress dengan perilaku disfungsional 
Christina Ayu Maha Dewi dan Anak Agung Ngurah Bagus Dwirandra. Peran...

auditor. Harapannya penelitian ini mampu memberikan gambaran dan pemahaman serta memperluas pengetahuan dan wawasan dilingkungan akademis. Memberikan manfaat bagi pihak-pihak yang berkepentingan khususnya mengenai teori perubahan sikap (Attitude Change Theory) dalam mengukur pengaruh role stress, moral reasoning, skeptisisme profesional, pada perilaku disfungsional auditor.

Hasil penelitian ini juga diharapkan dapat menjadi suatu masukan atau pertimbangan bagi pihak auditor dalam meningkatkan kinerja auditor internal dalam menjalankan tugasnya. Penelitian ini juga diharapkan dapat memberikan tambahan pengetahuan tentang pengaruh role stress, moral reasoning, skeptisisme profesional, dan prilaku disfungsional auditor.

Adapun kerangka konseptual dalam penelitian ini menunjukkan pengaruh antar variabel dalam penelitian. Kerangka berpikir dalam penelitian ini disajikan pada gambar 1 sebagai berikut.

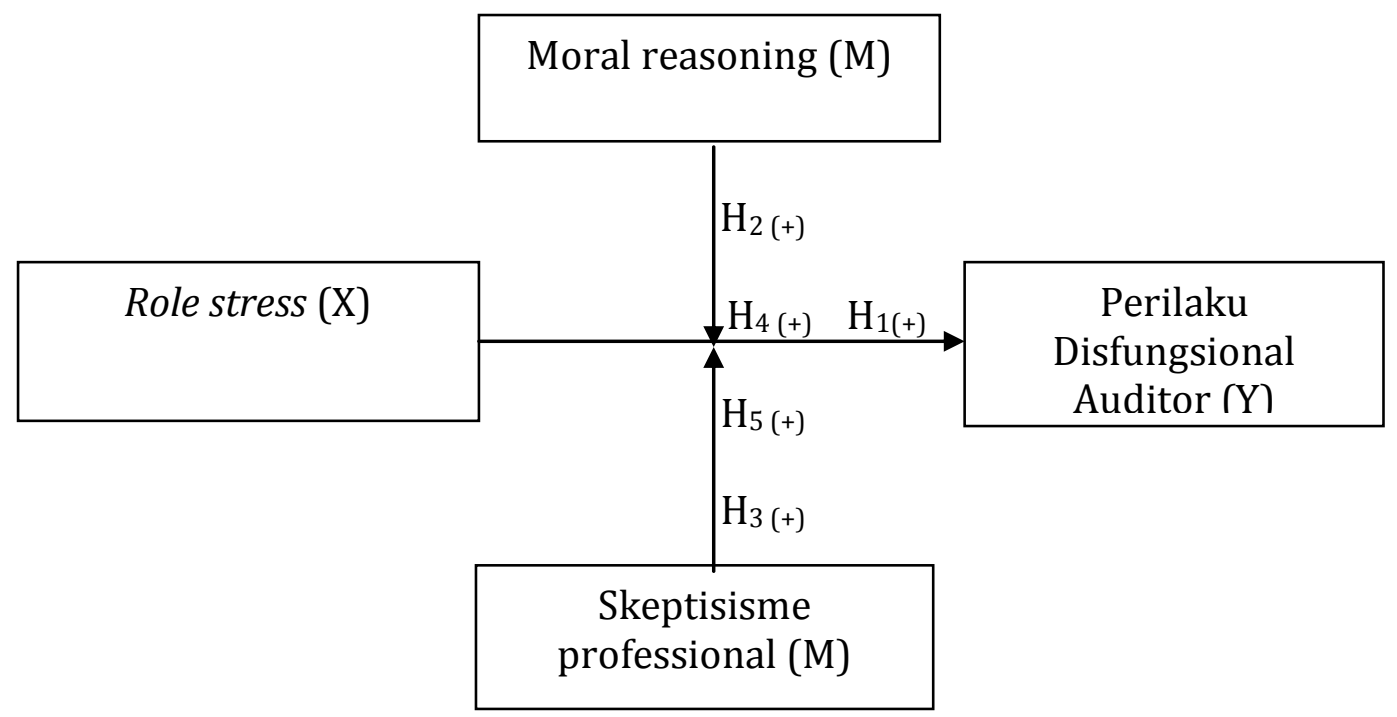

Gambar 1. Model Kerangka Berfikir 
Attitude change theory merupakan model yang sering digunakan dalam menjelaskan hubungan antara kejenuhan kerja dan hasil pekerjaan (Alan \& Todd, 2011). Menurut Robbins dan Judge (2011:97), prilaku yang berlebihan akan menempatkan tuntutan yang tidak dapat dicapai, yang mengakibatkan hasil pekerjaan menurun. Hal ini relevan dengan kejenuhan kerja sangat besar akan menyebabkan tingkat stres yang tinggi yang berpengaruh terhadap karakteristik personal auditor sehingga melakukan perilaku disfungsional audit (Nelson, 2009).

Beberapa penelitian seperti Rustiarini (2014) membuktikan bahwa terdapat pengaruh positif role stress terhadap perilaku disfungsional auditor. Alkautsar (2014) perilaku disfungsional auditor dipengaruhi oleh role stress yang dialami oleh auditor. Dikdik (2008) dalam penelitiannya membuktikan ada pengaruh positif role stress terhadap perilaku disfungsional auditor dalam melaksanakan audit perusahaan. Dari penjelasan di atas, maka hipotesis yang dapat dirumuskan adalah sebagai berikut:

$\mathrm{H}_{1} \quad$ : role stress berpengaruh positif pada perilaku disfungsional auditor.

Kemudian teori disonansi kognitif dapat menjelaskan bahwa moral reasoning merupakan upaya dalam memecahkan masalah moral dengan menggunakan logika yang sehat. Seseorang harus mampu memahami dengan baik masalah yang sedang dihadapi seperti apa yang akan diambilnya sehingga memiliki hasil yang berkualitas dan menghindari terjadinya perilaku disfungsional auditor (Tangsakul \& Ussahawanitchakit, 2015).

Beberapa penelitian seperti Tangsakul \& Ussahawanitchakit (2015) menyatakan bahwa moral reasoning berpengaruh terhadap perilaku disfungsional 
Christina Ayu Maha Dewi dan Anak Agung Ngurah Bagus Dwirandra. Peran...

auditor. Syarhayuti \& Faidul (2016) menyatakan bahwa moral reasoning secara tidak langsung mempengaruhi perilaku disfungsional auditor. Hanifah (2017) dalam penelitiannya membuktikan ada pengaruh moral reasoning terhadap perilaku disfungsional auditor. Berdasarkan uraian tersebut maka hipotesis yang diajukan adalah sebagai berikut:

$\mathrm{H}_{2} \quad$ : moral reasoning berpengaruh positif pada perilaku disfungsional auditor.

Di samping itu atribusi menyebabkan diri auditor harus menggunakan keahlian profesionalnya untuk merencanakan dan melaksanakan auditnya dengan baik. Auditor harus menggunakan keahliannya dengan cermat untuk rencanakan prosedur audit dan mengevaluasi bukti yang diperoleh, dengan demikian auditor akan dapat menghindari terjadinya prilaku disfungsional auditor Medhat \& Gary, 2015).

Beberapa penelitian seperti Quadackers et al. (2008) menyatakan bahwa skeptisisme profesional berpengaruh terhadap perilaku disfungsional auditor. Nelson (2009) menyatakan bahwa skeptisisme profesional secara tidak langsung mempengaruhi perilaku disfungsional auditor. Medhat \& Gary (2015) menyatakan hal yang sama dimana skeptisisme profesional berpengaruh secara positif pada perilaku disfungsional auditor. Berdasarkan uraian tersebut maka hipotesis yang diajukan adalah sebagai berikut:

$\mathrm{H}_{3}$ : Skeptisisme profesional auditor berpengaruh positif terhadap perilaku disfungsional auditor.

Dissonance theory menjelaskan tingkat moral reasoning seorang auditor dalam memberikan persepsi etis dari kasus pelanggaran etika akan mendasarkan perilaku akuntan tersebut pada prinsip-prinsip moral. Tinggi rendahnya role stress 
yang dimiliki seorang auditor internal salah satunya dipengaruhi oleh moral reasoning, dikarenakan moral reasoning dapat menghasilkan tingkat role stress yang tinggi ataupun rendah dan selanjutnya dapat mempengaruhi perilaku disfungsional auditor (Mahatma dan Suaryana, 2016).

Beberapa penelitian seperti Suriana (2014) menyatakan moral reasoning memoderasi pengaruh role stress secara positif pada perilaku disfungsional auditor. Hanifah (2017) dalam penelitiannya membuktikan ada pengaruh positif role stress terhadap perilaku disfungsional auditor yang dimoderasi oleh moral reasoning. Sudarshan (2015) dalam penelitiannya membuktikan ada pengaruh positif role stress terhadap perilaku disfungsional auditor yang dimoderasi oleh moral reasoning. Berdasarkan uraian tersebut maka hipotesis yang diajukan adalah sebagai berikut: .

$\mathrm{H}_{4} \quad$ : Moral reasoning memperkuat pengaruh role stress terhadap perilaku disfungsional auditor.

Penelitian seperti Medhat \& Gary (2015) menyatakan hal yang sama dimana skeptisisme profesional memodarasi pengaruh role stress secara positif pada perilaku disfungsional auditor. Nelson (2009) dalam penelitiannya membuktikan ada pengaruh positif role stress terhadap perilaku disfungsional auditor yang dimoderasi oleh skeptisisme profesional. David \& Kasey (2016) menyatakan variabel skeptisisme profesional memodarasi pengaruh role stress secara positif pada perilaku disfungsional auditor. Berdasarkan uraian tersebut maka hipotesis yang diajukan adalah sebagai berikut:

$\mathrm{H}_{5}$ : Skeptisisme profesional memperkuat pengaruh role stress terhadap perilaku disfungsional auditor. 


\section{METODE PENELITIAN}

Penelitian ini digolongkan pada penelitian asosiatif (hubungan), yaitu penelitian yang bertujuan untuk mengetahui hubungan dari variabel atau lebih (Sugiyono, 2009 :5). Penelitian ini dilakukan di kantor Inspeksi (Kanins) PT. Bank BRI Kanwil Bali-Nusra dengan wilayah 29 kantor cabang terdiri dari kantor cabang Denpasar gatot subroto, Kuta, Gianyar, Ubud, Tabanan, Bangli, Negara, Waikabubak, Waingapu, Denpasar gajah mada, Singaraja, Klungkung, Karangasem, Mataram, Praya, Selong, Raba bima, Dompu, Sumbawa besar, Kupang, Soe, Kefamenanu, Atambua, Kalabahi, Larantuka, Maumere, Ende, Bajawa dan cabang Ruteng dengan masing-masing cabang mewilayahi unit kerja, kantor kas dan teras di Daerah masing-masing, tahun 2017. Objek penelitian dalam penelitian ini adalah perilaku disfungsional auditor pada PT. Bank BRI Kanwil Bali-Nusra yang dipengaruhi oleh role stress dengan moderasi moral reasoning dan skeptisisme profesional.

Berdasarkan rumusan masalah serta hipotesis penelitian yang telah dipaparkan, dapat diidentifikasi perilaku disfungsional auditor. (Y) sebagai variabel dependen diproksikan dengan 3 indikator yang dikembangkan oleh (Ongky, 2012) yaitu pemahaman prilaku disfungsional auditor melalui pernyataan sebagai berikut. 1) Underrepotting of time atau waktu pelaporan audit; 2)Premature sign-off atau penghentian prematur audit; 3)Altering/replacing of audit proceduresi atau penggantian prosedur audit.

Role stress yang merupakan variabek independen diukur melalui berbagai indikasi dipengaruhi oleh empat indikator. 1) Mempunyai kesadaran akan terjadi 
konflik; 2) Menerima kondisi dan situasi jika muncul konflik yang dapat membuat tekanan-tekanan dalam pekerjaan; 3) Memiliki kemampuan untuk menoleransi stress; 4) Memperkuat sikap atau sifat pribadi lebih tahan dalam menghadapi konflik yang muncul dalam organisasi

Kemudian Moral reasoning sebagai variabel pemoderasi menggunakan kuesioner untuk mengukur moral reasoning yang terdiri atas 5 item pernyataan indikator dari Hanifah (2017) antara lain: 1) Prinsip keadilan moral; 2) Etika dengan nilai-nilai bersifat umum terikat pada budaya; 3) Tidak melanggar etis yang menguntungkan diri sendiri; 4) Pelaksanaan audit konsekuensi dengan meminimalkan biaya; 5) Logika mengidentifikasi tugas yang akan dilakukan.

Skeptisisme professional diukur dengan menggunakan instrument yang dikembangkan oleh Syarhayuti (2016). Instrumen terdiri dari 6 item yaitu. 1) Memiliki sikap skeptik; 2) Sikap skeptis menemukan pelanggaran; 3) Evaluasi hasil temuan; 4) Tuntutan professional; 5) Bersikap cermat serta seksama; 6) Bersikap profesionalisme.

Metode yang digunakan dalam pengumpulan data dalam penelitian ini yakni wawancara dan dengan teknik kuisoner. Dilakukan Uji instrument, Uji Statistik Deskriptif, Uji Asumsi Klasik hingga Uji Moderated Regression Analysis (MRA) yang menghasilkan persamaan sebagai berikut.

$$
\mathrm{Y}=\alpha+\beta_{1} \mathrm{X}_{+} \beta_{2} \mathrm{M}_{1+} \beta_{3} \mathrm{M}_{2+} \beta_{4}\left(\mathrm{XM}_{1}\right)+\beta_{5}\left(\mathrm{XM}_{2}\right) \mathrm{e}
$$

Keterangan:

$\mathrm{Y}=$ perilaku disfungsional auditor

$\alpha \quad=$ konstanta

$\beta_{1}, \beta_{5}, \quad=$ koefisien regresi moderasi masing-masing variabel independen

$\mathrm{X} \quad=$ role stress

$\mathrm{M}_{1} \quad=$ moral reasoning 
Christina Ayu Maha Dewi dan Anak Agung Ngurah Bagus Dwirandra. Peran...

$\mathrm{M}_{2} \quad$ = skeptisisme profesional

e $\quad=$ error term yaitu faktor kesalahan dalam penelitian

\section{HASIL DAN PEMBAHASAN}

Penelitian ini dilakukan untuk mengetahui moral reasoning dan skeptisisme profesional memoderasi role stress terhadap perilaku disfungsional auditor di PT Bank BRI Wilayah Bali-Nusra. Data dikumpulkan dengan menyebar kuesioner ke 29 kantor PT Bank BRI Wilayah Bali-Nusra. Ringkasan kuesioner dapat dilihat pada tabel 1 sebagai berikut.

Tabel 1.

Rincian Pengiriman dan Pengembalian Kuesioner

\begin{tabular}{lcc}
\hline \multicolumn{1}{c}{ Kuesioner } & Jumlah & Persentase \\
\hline Kuesioner yang disebar & 107 & $100 \%$ \\
Kuesioner yang tidak kembali & 11 & $10,2 \%$ \\
Kuesioner yang kembali & 96 & $89,8 \%$ \\
Kuesioner yang digugurkan & 11 & $10,2 \%$ \\
Kuesioner yang digunakan & 96 & $89,8 \%$ \\
Tingkat pengembalian kuisioner & $96 / 107 \times 100 \%=$ & $89,8 \%$ \\
Kuisioner yang digunakan & $96 / 107 \times 100 \%=$ & $89,8 \%$ \\
\hline
\end{tabular}

Sumber: Data Diolah, 2017

Tabel 1 menunjukan bahwa kuesioner yang disebar ke responden sebanyak 107 kuesioner dan yang terkumpul sebanyak 96. Terdapat kueisoner yang tidak kembali dan terdapat kuesioner yang digugurkan yaitu sebanyak 11 kuesioner, sehingga secara keseluruhan jumlah kuesioner yang layak digunakan untuk dianalisis sebanyak 96 kuesioner.

Statistik deskriptif digunakan untuk mengetahui jumlah sampel, nilai minimum, nilai maksimum, nilai rata-rata, dan standar deviasi dari masing-masing variabel. Hasil statistik deskriptif dapat dilihat pada Tabel 2 sebagai berikut. 
Tabel 2.

Hasil Statistik Deskriptif

\begin{tabular}{lccccc}
\hline \multicolumn{1}{c}{ Variabel } & N & Min. & Max. & Mean & $\begin{array}{c}\text { Std. } \\
\text { Deviasi }\end{array}$ \\
\hline Role Stress & 96 & 9 & 19 & 15,10 & 1,938 \\
Moral Reasoning & 96 & 13 & 23 & 18,95 & 2,464 \\
Skeptisisme Profesional & 96 & 13 & 28 & 22,38 & 3,096 \\
Role Stress- Moral Reasoning & 96 & 117 & 437 & 286,84 & 53,670 \\
$\begin{array}{l}\text { Role Stress- Skeptisisme } \\
\text { Profesional }\end{array}$ & 96 & 117 & 532 & 341,11 & 78,914 \\
Perilaku Disfungsional Auditor & 96 & 8 & 15 & 11,55 & 1,094 \\
\hline Sumber: Data Primer Diolah, 2017 & (Lampiran 5) & & &
\end{tabular}

Tabel 2 dapat dilihat bahwa variabel role stress $(\mathrm{X})$ memiliki nilai minimum sebesar 9, nilai maksimum sebesar 19, mean sebesar 15,10, dan standar deviasi sebesar 1,938 . Ini berarti bahwa terjadi perbedaan nilai role stress yang diteliti terhadap nilai rata-ratanya sebesar 1,938 .

Variabel moral reasoning (M1) memiliki nilai minimum sebesar 13, nilai maksimum sebesar 23, mean sebesar 18,95, dan standar deviasi sebesar 2,464. Ini berarti bahwa terjadi perbedaan nilai moral reasoning yang diteliti terhadap nilai rata-ratanya sebesar 2,464. Variabel skeptisisme profesional (M2) memiliki nilai minimum sebesar 13 , nilai maksimum sebesar 28 , mean sebesar 22,38, dan standar deviasi sebesar 3,096. Ini berarti bahwa terjadi perbedaan nilai skeptisisme profesional yang diteliti terhadap nilai rata-ratanya sebesar 3,096.

Variabel role stress $(\mathrm{X})$ - moral reasoning (M1) memiliki nilai minimum sebesar 117, nilai maksimum sebesar 437, mean sebesar 286,84, dan standar deviasi sebesar 53,670. Ini berarti bahwa terjadi perbedaan nilai role stress $(\mathrm{X})$ moral reasoning (M1) yang diteliti terhadap nilai rata-ratanya sebesar 53,670.

Variabel role stress (X) - skeptisisme profesional (M2) memiliki nilai minimum sebesar 117 , nilai maksimum sebesar 532, mean sebesar 341,11, dan 
standar deviasi sebesar 78,914. Ini berarti bahwa terjadi perbedaan nilai role stress (X) - moral reasoning (M1) yang diteliti terhadap nilai rata-ratanya sebesar 78,914 .

Variabel perilaku disfungsional auditor (Y) memiliki nilai minimum sebesar 8 , nilai maksimum sebesar 15 , mean sebesar 11,55 , dan standar deviasi sebesar 1,094. Ini berarti bahwa terjadi perbedaan nilai perilaku disfungsional auditor yang diteliti terhadap nilai rata-ratanya sebesar 1,094. Jumlah responden yang dijadikan sampel dalam penelitian ini adalah sebanyak 96 orang dengan penilaian peran moral reasoning dan skeptisisme profesional memoderasi role stress terhadap perilaku disfungsional auditor di PT Bank BRI Wilayah BaliNusra.

Pengujian validitas tiap butir digunakan analisis item yaitu mengkorelasikan skor tiap item dengan skor total item. Jika korelasi item terhadap skor total lebih besar dari $\mathrm{r}$ kritis $(0,30)$ maka instrumen dikatakan valid yang disajikan padayang disajikan pada Tabel 3 berikut.

Tabel 3. Hasil Uji Validitas

\begin{tabular}{|c|c|c|}
\hline Variabel & Instrumen & $\begin{array}{c}\text { Pearson } \\
\text { Correlation }\end{array}$ \\
\hline \multirow{4}{*}{ Role stress $(\mathrm{X})$} & $\mathrm{X}_{1.1}$ & 0,803 \\
\hline & $\mathrm{X}_{1.2}$ & 0,824 \\
\hline & $\mathrm{X}_{1.3}$ & 0,783 \\
\hline & $\mathrm{X}_{1.4}$ & 0,745 \\
\hline \multirow{5}{*}{ Moral reasoning (M1) } & $\mathrm{M}_{1.1}$ & 0,737 \\
\hline & $\mathrm{M}_{1.2}$ & 0,869 \\
\hline & $\mathrm{M}_{1.3}$ & 0,801 \\
\hline & $\mathrm{M}_{1.4}$ & 0,686 \\
\hline & $\mathrm{M}_{1.5}$ & 0,757 \\
\hline
\end{tabular}




\begin{tabular}{lll}
\hline & $\mathrm{M}_{2.1}$ & 0,862 \\
& $\mathrm{M}_{2.2}$ & 0,762 \\
Skeptisisme profesional (M2) & $\mathrm{M}_{2.3}$ & 0,846 \\
& $\mathrm{M}_{2.4}$ & 0,714 \\
& $\mathrm{M}_{2.5}$ & 0,722 \\
& $\mathrm{M}_{2.6}$ & 0,771 \\
& $\mathrm{Y}_{1}$ & 0,847 \\
Perilaku disfungsional auditor (Y) & $\mathrm{Y}_{2}$ & 0,915 \\
& $\mathrm{Y}_{3}$ & 0,894 \\
\hline
\end{tabular}

Sumber: Data diolah, 2017

Tabel 3 dibawah terlihat variabel role stress memiliki pearson correlation dari $0,745-0,824(>0,30)$, hal ini berarti bahwa pernyataan tersebut valid. Variabel moral reasoning memiliki pearson correlation dari $0,686-0,869$ (> 0,30), hal ini berarti bahwa pernyataan tersebut valid. Variabel skeptisisme profesional memiliki pearson correlation dari $0,714-0,862(>0,30)$, hal ini berarti bahwa pernyataan tersebut valid. Variabel perilaku disfungsional auditor memiliki pearson correlation dari $0,847-0,915(>0,30)$, hal ini berarti bahwa pernyataan dalam kuesioner adalah valid.

Pengujian instrument selanjutnya reliabilitas dalam penelitian ini menggunakan metode Cronbach's Alpha. Hasil pengujian reliabilitas instrumen dapat dilihat pada Tabel 4.

Tabel 4.

Hasil Uji Reliabilitas

\begin{tabular}{lc}
\hline \multicolumn{1}{c}{ Variabel } & Cronbach's Alpha \\
\hline Role stress (X) & 0,789 \\
Moral reasoning (M1) & 0,827 \\
Skeptisisme profesional (M2) & 0,872 \\
Perilaku disfungsional auditor (Y) & 0,859 \\
\hline Sumber: Data diolah, 2017
\end{tabular}


Christina Ayu Maha Dewi dan Anak Agung Ngurah Bagus Dwirandra. Peran...

Tabel 4 menjelaskan bahwa pernyataan dalam kuesioner tersebut reliabel. Hal ini ditujukan dengan nilai alpha untuk masing-masing variabel lebih besar dari R alpha tabel yaitu 0,60. Selanjutnya dilakukan uji asumsi klasik yang meliputi uji normalitas, uji multikolinearitas dan uji heteroskedastisitas untuk mengetahui apakah data dalam penelitian yang dilakukan telah lolos dari asumsi klasik. Dari hasil uji diketahui nilai signifikansi sebesar 0,092 (0,092 > 0,05). Hal ini berarti model regresi berdistribusi normal.

Uji kedua yang dilakukan yakni uji multikolinearitas dalam model regresi tidak terjadi multikolinearitas dan dapat digunakan dalam penelitian hal ini dapat dilihat bahwa nilai tolerence masing-masing variabel lebih kecil dari 0,1 dan nilai VIF lebih besar dari 10. Uji Heteroskedastisitas didapatkan hasil bahwa nilai sig. masing-masing variabel lebih besar dari 0,05 yang berarti variabel tersebut bebas heteroskedastisitas. Moderated Regression Analysis (MRA) digunakan dalam model persamaan regresi linear berganda untuk pengaruh antar variabel yang dibentuk.

Tabel 5.

Hasil Pelaporan Analisis MRA

\begin{tabular}{|c|c|c|c|c|c|}
\hline \multirow{2}{*}{\multicolumn{2}{|c|}{ Variabel }} & \multicolumn{3}{|c|}{ Koefisien Regresi } & \multirow[b]{2}{*}{ Sig } \\
\hline & & B & $\begin{array}{l}\text { Std. } \\
\text { error }\end{array}$ & $\mathbf{t}$ & \\
\hline (constant) & & -9.931 & 5.335 & & \\
\hline Role Stress & & 1.474 & 0.378 & 3.898 & .000 \\
\hline Moral Reasoning & & 0.013 & 0.259 & 0.049 & .001 \\
\hline Skeptisisme Profes & & 0,832 & 0.179 & 4.650 & .000 \\
\hline Role Stress-Moral & $g \mid$ ZXM1 | & 0,003 & 0.017 & 0.201 & .041 \\
\hline Role Stress- Skepti & fesional $\mid$ ZXM2 | & 0,055 & 0.011 & 4.873 & .000 \\
\hline Dependen variabel & \multicolumn{5}{|c|}{ Perilaku disfungsional auditor } \\
\hline F Statistik & \multicolumn{5}{|l|}{9.435} \\
\hline Sig F & \multicolumn{5}{|l|}{0.000} \\
\hline $\mathrm{R}^{2}$ & \multicolumn{5}{|l|}{0.944} \\
\hline
\end{tabular}


Persamaan regresi pada Tabel 4.16, dapat dijelaskan untuk setiap variabel hal-hal sebagai berikut:

$$
\mathrm{Y}=-9,931+1,474 \mathrm{X}+0,013 \mathrm{M}_{1}+0,832 \mathrm{M}_{2}+0,003 \mathrm{ZXM} 1+0,055 \mathrm{ZXM} 2
$$

Nilai konstanta yang diperoleh adalah sebesar -9,931 menunjukan bahwa apabila perubahan variabel bebas dan moderasi yaitu role stress, moral reasoning dan skeptisisme profesional sama dengan nol atau bersifat konstan, maka perilaku disfungsional auditor mengalami penurunan pada PT Bank BRI Wilayah BaliNusra. Nilai Koefisien $\beta_{1}$ yang diperoleh sebesar 1,474 menunjukan bahwa interaksi antara variabel role stress dan perilaku disfungsional auditor bersifat positif. Artinya interaksi role stress berpengaruh terhadap perilaku disfungsional auditor pada PT Bank BRI Wilayah Bali-Nusra. Nilai Koefisien $\beta_{2}$ yang diperoleh sebesar 0,013 menunjukan bahwa interaksi antara variabel moral reasoning dan perilaku disfungsional auditor bersifat positif. Artinya interaksi moral reasoning berpengaruh terhadap perilaku disfungsional auditor pada PT Bank BRI Wilayah Bali-Nusra.

Nilai Koefisien $\beta_{3}$ yang diperoleh sebesar 0,832 menunjukan bahwa interaksi antara variabel skeptisisme profesional dan perilaku disfungsional auditor bersifat positif. Artinya interaksi skeptisisme profesional berpengaruh terhadap perilaku disfungsional auditor pada PT Bank BRI Wilayah Bali-Nusra. Nilai Koefisien $\beta_{4}$ yang diperoleh sebesar 0,003 menunjukan bahwa interaksi antara variabel moral reasoning dan role stress bersifat positif. Artinya interaksi moral reasoning memperkuat pengaruh role stress terhadap perilaku disfungsional auditor pada PT Bank BRI Wilayah Bali-Nusra. Nilai Koefisien $\beta_{5}$ yang diperoleh sebesar 0,055 menunjukan bahwa interaksi antara variabel skeptisisme profesional dan role 
Christina Ayu Maha Dewi dan Anak Agung Ngurah Bagus Dwirandra. Peran...

stress bersifat positif. Artinya interaksi skeptisisme profesional memperkuat pengaruh role stress terhadap perilaku disfungsional auditor pada PT Bank BRI Wilayah Bali-Nusra.

Hasil uji statistik F pada Tabel 5, menunjukan hasil nilai siginifikansi sebesar 0,000 yang lebih kecil dari tingkat $\alpha=0,05$. Hal ini berarti role stress, moral reasoning dan skeptisisme profesional secara bersama berpengaruh signifikan terhadap perilaku disfungsional auditor pada PT Bank BRI Wilayah Bali-Nusra. Hal ini mengindikasikan bahwa model yang digunakan dalam penelitian ini layak dipergunakan. Berdasarkan Tabel 5, menunjukan bahwa nilai adjusted $\mathrm{R}$ square model 0,944 atau sebesar 94,4\% artinya sebesar 5,6\% variasi atau perilaku disfungsional auditor dapat dijelaskan oleh variasi variabel dalam model tersebut yaitu role stress, moral reasoning dan skeptisisme profesional.

Hasil uji parsial menunjukan bahwa role stress berpengaruh positif dan signifikan terhadap perilaku disfungsional auditor pada PT Bank BRI Wilayah Bali-Nusra. Attitude change theory merupakan model yang sering digunakan dalam menjelaskan hubungan antara kejenuhan kerja dan hasil pekerjaan (Alan \& Todd, 2011). Menurut Robbins dan Judge (2011:97), prilaku yang berlebihan akan menempatkan tuntutan yang tidak dapat dicapai, yang mengakibatkan hasil pekerjaan menurun.

Beberapa penelitian seperti Rustiarini (2014) membuktikan bahwa terdapat pengaruh positif role stress terhadap perilaku disfungsional auditor. Alkautsar (2014) perilaku disfungsional auditor dipengaruhi oleh role stress yang dialami oleh auditor. Dikdik (2008) dalam penelitiannya membuktikan ada pengaruh 
positif role stress terhadap perilaku disfungsional auditor dalam melaksanakan audit perusahaan PT Sari Ater Hot Spring Resort Hotel.

Moral reasoning dalam uji parsial menunjukan hasil yakni berpengaruh positif dan signifikan terhadap perilaku disfungsional auditor pada PT Bank BRI Wilayah Bali-Nusra. Hubungan antara moral reasoning dengan hasil audit yang memiliki penalaran moral dalam memecahkan masalah moral dengan menggunakan logika yang sehat memberikan hasil kualitas internal audit lebih baik dan menghindari terjadinya perilaku disfungsional auditor (Tangsakul \& Ussahawanitchakit, 2015). Dengan demikian penalaran moral bukanlah tentang apa yang baik atau yang buruk, tetapi tentang bagaimana seseorang berpikir sampai pada keputusan bahwa sesuatu adalah baik atau buruk (Kohlberg, 1977: 1981 dalam (Pillalamarri \& Holm, n.d.).

Hasil penelitian ini sama dengan penelitian Tangsakul \& Ussahawanitchakit (2015) menyatakan bahwa moral reasoning berpengaruh terhadap perilaku disfungsional auditor in Thailand. Syarhayuti \& Faidul (2016) menyatakan bahwa moral reasoning secara tidak langsung mempengaruhi perilaku disfungsional auditor di Inspektorat Provinsi Sulawesi Selatan. Hanifah (2017) dalam penelitiannya membuktikan ada pengaruh moral reasoning terhadap perilaku disfungsional auditor KAP di Provinsi DKI Jakarta.

Kemudian Hasil uji parsial menunjukan bahwa skeptisisme profesional berpengaruh positif dan signifikan terhadap perilaku disfungsional auditor pada PT Bank BRI Wilayah Bali-Nusra. Hasil penelitian ini sama dengan penelitian Quadackers et al. (2008) menyatakan bahwa skeptisisme profesional berpengaruh 
Christina Ayu Maha Dewi dan Anak Agung Ngurah Bagus Dwirandra. Peran...

terhadap perilaku disfungsional auditor in Big Four auditing in Netherlands. Nelson (2009) menyatakan bahwa skeptisisme profesional secara tidak langsung mempengaruhi perilaku disfungsional auditor in American Accounting Association. Medhat \& Gary (2015) menyatakan hal yang sama dimana skeptisisme profesional berpengaruh secara positif pada perilaku disfungsional auditor Big 4 audit firms in Egypt and Australia.

Untuk hasil uji parsial selanjutnya menunjukan bahwa moral reasoning memperkuat pengaruh positif dan signifikan role stress terhadap perilaku disfungsional auditor pada PT Bank BRI Wilayah Bali-Nusra. Dissonance theory menjelaskan tingkat moral reasoning seorang auditor dalam memberikan persepsi etis dari kasus pelanggaran etika akan mendasarkan perilaku akuntan tersebut pada prinsip-prinsip moral. Tinggi rendahnya role stress yang dimiliki seorang auditor internal salah satunya dipengaruhi oleh moral reasoning, dikarenakan moral reasoning dapat menghasilkan tingkat role stress yang tinggi ataupun rendah dan selanjutnya dapat mempengaruhi perilaku disfungsional auditor (Mahatma dan Suaryana, 2016).

Hasil penelitian ini sama dengan penelitian Suriana (2014) menyatakan moral reasoning memperkuat pengaruh role stress secara positif pada perilaku disfungsional auditor pada BPK RI Provinsi Maluku. Hanifah (2017) dalam penelitiannya membuktikan ada pengaruh positif role stress terhadap perilaku disfungsional auditor yang diperkuat oleh moral reasoning KAP di Provinsi DKI Jakarta. Sudarshan (2015) dalam penelitiannya membuktikan ada pengaruh positif 
role stress terhadap perilaku disfungsional auditor yang diperkuat oleh moral reasoning students universities in Denmark.

Hasil uji parsial yang terakhir menunjukan bahwa skeptisime profesional memoderasi pengaruh positif dan signifikan role stress terhadap perilaku disfungsional auditor pada PT Bank BRI Wilayah Bali-Nusra. Hasil penelitian ini sama dengan penelitian Medhat \& Gary (2015) menyatakan hal yang sama dimana skeptisisme profesional memperkuat pengaruh role stress secara positif pada perilaku disfungsional auditor Big 4 audit firms in Egypt and Australia. Nelson (2009) dalam penelitiannya membuktikan ada pengaruh positif role stress terhadap perilaku disfungsional auditor yang diperkuat oleh skeptisisme professional in American Accounting Association. David \& Kasey (2016) menyatakan variabel skeptisisme profesional memperkuat pengaruh role stress secara positif pada perilaku disfungsional auditor American Accounting Association.

\section{SIMPULAN}

Berlandaskan hasil analisis dapat disimpulkan sebagai berikut. 1) Role stress berpengaruh positif signifikan terhadap perilaku disfungsional auditor pada PT Bank BRI Wilayah Bali-Nusra; 2) Moral reasoning berpengaruh positif signifikan terhadap perilaku disfungsional auditor pada PT Bank BRI Wilayah Bali-Nusra; 3) Skeptisisme profesional berpengaruh positif signifikan terhadap perilaku disfungsional auditor pada PT Bank BRI Wilayah Bali-Nusra; 4) Moral reasoning memperkuat pengaruh positif role stress terhadap perilaku disfungsional auditor pada PT Bank BRI Wilayah Bali-Nusra; 5) Skeptisisme profesional memperkuat 
pengaruh positif role stress terhadap perilaku disfungsional auditor pada PT Bank BRI Wilayah Bali-Nusra.

Saran yang dapat diberikan dalam penelitian ini yakni seorang auditor yang mengalami tingkat role stress cenderung mempermasalahkan tuntutan pekerjaannya yang tidak sesuai dengan kemampuan yang dimilikinya, sebagai pihak yang bertanggung jawab kantor Inspeksi PT Bank BRI harus memperhatikan segala pekerjaan yang dibebankan kepada auditor seperti jumlah pemeriksaan, waktu pemeriksaan untuk pelaporan yang akan membantu pihak auditor untuk bekerja secara baik dan mengurangi perilaku disfungsional.

Kemudian kantor Inspeksi PT Bank BRI harus memberikan pemahaman dan pelatihan terhadap budaya kerja untuk auditor sehingga mampu bekerja sesuai etika dan nilai-nilai perusahaan untuk mengurangi terjadinya perilaku disfungsional auditor. Peneliti selanjutnya diharapkan dapat mengambil variabel lainnya selain role stress, moral reasoning, skeptisisme dalam mengukur perilaku disfungsional auditor seperti kompetensi, ethical sensitivity, dengan menerapkan di lokasi penelitian yang lain seperti KAP, pemerintahan dan lainnya.

\section{REFERENSI}

Alan T Lord, F Todd Dezoort. 2011. The Impact of Commitment and Moral Reasoning on Auditors Response to Social Influence Pressure. International Journal of Accounting, Organization and Society. 2(6): h: 215-235

Alkautsar, Muslim., 2014. Locus of Control, Commitment Profesional and Dysfunctional Audit Behaviour. International Journal of Humanities and Management Sciences. 2(1): h: 35-38

Anggriawan, ferry eko. (2014). Pengaruh Pengalaman Kerja, Skeptisme Profesional dan Tekanan Waktu Terhadap Kemampuan Auditor dalam 
Mendeteksi Fraud (Studi Empiris Pada Kantor Akuntan Publik Di DIY. Jurnal Nominal/Volume III Nomor 2/ Tahun 2014, III(2)

Arens, Alvin A. Elder, Randal J dan Beasley, Mark S. 2008. “ Auditing dan Jasa Asuransi Pendekatan Terintegrasi”. Jilid 2, Edisi keduabelas, Erlangga.

Arens, Alvin A. and James K. Loebbecke. 2003. Auditing: An Integrated Approach. $7^{\text {th }}$ Edition. Prentice Hall Inc.

Balkish Zakaria, Nor., Nurhidayah Yahya, Kalsom Salleh. 2013. Dysfunctional Behavior among Auditors: The Application of Occupational Theory. Journal of Basic and Applied Scientific Research. 3(9): h: 495-503

Ceacilia Sri Mindarti, Pancawati Hardiningsih, Rachmawati Meita Oktaviani. 2016. Moral Reasoning memoderasi Kompetensi dan Independensi Terhadap Audit. Jurnal Simposium Nasional Akuntansi. 11(1): h:1-25

David N. Herda, Kasey A. Martin. 2016. The Effects of Auditor Experience and Professional Commitment on Acceptance of Underreporting Time: A Moderated Mediation Analysis. International Journal of American Accounting Association. 10(2): h: 14-27

Dikdik, A. 2008. Pengaruh Role tress Terhadap Perilaku Disfungsional Internal Auditor. Dimensia, 5(1).

Desmond C.Y. Yuen, Philip K.F. Law, Chan Lu, Jie Qi Guan. 2012. Dysfunctional Auditing Behaviour: Empirical Evidence on Auditors' Behaviour in Macau. International Journal of Accounting and Information Management. 4(5): h: 1-20

Donnelly, David P., Jeffrey J. Quirin. 2013. Attitudes Toward Dysfunctional Audit Behavior: The Effects Of Locus Of Control, Organizational Commitment, and Position. Journal of Applied Business Research. 19(1): h: $96-108$

Faisal. 2007. Tekanan Pengaruh Sosial dalam Menjelaskan Hubungan Moral Reasoning Terhadap Keputusan Auditor. Jurnal Akuntansi dan Keuangan. 4(1): h: $25-46$

Gaffikin, Michael and Lindawati. 2012, The Moral Reasoning of Public Accountants in the Development of a Code of Ethics: the Case of Indonesia. International Journal of Australasian Accounting, Business and Finance. 6(1): h: 3-28

Hanifah, Nur., 2017. Pengaruh Time Budget Pressure, Kompensasi dan Moral Reasoning terhadap Dysfunctional Audit Behavior dan Dampaknya 
terhadap Kualitas Audit. Jurnal Simposium Nasional Akuntansi. 3(2): h:134

Indri Septiani, Ni Made, Sukartha, I Made. 2017. Pengaruh Kompleksitas Audit dan Skeptisme Profesional Auditor pada Penerimaan Perilaku Disfungsional Audit. Jurnal Akuntansi Universitas Udayana. 18(1): h: 471-499

Luc Quadackers, Tom Groot, Arnold Wright. 2008. Auditors' Skeptical Characteristics and Their Relationship to Skeptical Judgments and Decisions. International Journal of Accounting, Organization and Society. 3(1): h: 1-47

Mahatma Setya Devi, Luh,. Suaryana I G.N.A,. 2016. Time Budget Pressure Memoderasi Pengaruh Karakteristik Personal Auditor terhadap Penerimaan Perilaku Disfungsional Audit. Jurnal Akuntansi Universitas Udayana. 15(3): h: 1994-2023

Maryam Sadeghi, Jamal Barzegari Khanagha, Mahmoud Naderibeni. 2014. Professional Commitment on Dysfunctional Audit Behaviour In audit organizations of Isfahan Public Accountancy. Interdisciplinary Journal of Contemporary Research in Business. 5(9): h: 275-283

Medhat Endrawes, Gary S. Monroe. 2015. Professional Scepticism of Auditors: A Cross-Cultural Experiment. International Journal of American Accounting Association. 51(2): h: 1-41

Nelson, M. W. 2009. A Model and Literature Review of Professional Skepticism in Auditing. International Journal of American Accounting Association. 28(2): h: $1-34$

Ongky Hartanto. 2012. Pengaruh Locus of Control, Tekanan Anggaran Waktu, Komitmen Profesional, Terhadap Perilaku Disfungsional Auditor. Jurnal Ekonomi dan Keuangan. 20(4): h: $473-490$

Peyman Tabatabaei Fakhar, Ali Hoseinzadeh. 2016. Investigate The Effect of Organizational Commitment and Professional Commitment on Dysfunctional Behavior of Auditors. International Academic Journal of Accounting and Financial Management. 3(1): h: 1-12

Rieke Sri Rizki Asti Karini. 2015. Stress Role and Dysfunctional Behavior on The Performance of Internal Auditor. Journal of Trikonomika. 14(2): h: 129137 
Rustiarini, Ni Wayan., 2013. Sifat Kepribadian sebagai Pemoderasi Hubungan Stres Kerja dan Perilaku Disfungsional Audit. Jurnal Akuntansi dan Keuangan Indonesia. 11(1): h: 1-19

Sartika. 2013. Pengaruh Sifat Mchiavellian dan Perkembangan Moral terhadap Perilaku Disfungsional. (Studi Empiris pada Perusahaan Manufaktur Kota Padang). Jurnal Simposium Nasional Akuntansi. 4(2): h:1-32

Siti Kustinah. 2013. The Influence of Dysfunctional Behavior And Individual Culture On Audit Quality. International Academic Journal of Scientific \& Technology Research. 2(5): h: 118-125

Sudarshan K. Pillalamarri. 2015. The Role of Moral Reasoning and Order Effects on Ethical Decision-Making Ability: Novice vs. Experienced Accounting Students. International Journal of American Accounting Association. 4(2): h: $1-22$

Sulastri Mustika, Dandes Rifa, Herawati. 2015. Pengaruh Moral Reasoning dan Professional Skepticism Auditor Pemerintah Terhadap Kualitas Audit Laporan Keuangan Pemerintah Daerah di Kota Padang. Jurnal Akuntansi dan Keuangan Indonesia. 2(1): h: 4-29

Syarhayuti, Faidul Adziem. 2016. Pengaruh Moral Reasoning, Skeptisme Profesional dan Kecerdasan Spiritual terhadap Kualitas Audit dengan Pengalaman Kerja Auditor sebagai variabel moderating di Inspektorat Provinsi Sulawesi Selatan. Jurnal Akuntansi Peradaban. 1(1): h: 128-148

Tangsakul, P., \& Ussahawanitchakit, P. (2015). Moral reasoning of tax auditors in Thailand an empirical investigation. He Business and Management Review, 7(1), 134-142. 